\title{
PRAKTIKALITAS PENGEMBANGAN E-BOOK FISIKA BERBANTUAN EDMODO BERBASIS DISCOVERY LEARNING DALAM PROSES PEMBELAJARAN FISIKA
}

\section{PRACTICALITY DEVELOPMENT OF EDMODO-ASSISTED PHYSICS E-BOOK BASED ON DISCOVERY LEARNING IN THE PYSICS LEARNING PROCESS}

\author{
Fitrah Ayu' ${ }^{\text {** }}$ Ahmad Fauzi ${ }^{2}$ \\ ${ }^{1,2}$ Program Studi Magister Pendidikan Fisika Fakultas MIPA Universitas Negeri Padang, Indonesia \\ *Email: fitrahayu97@yahoo.com
}

Diterima: 16 September 2020. Disetujui: 23 Oktober 2020. Dipublikasikan: 25 Desember 2020

\begin{abstract}
Abstrak: Tujuan penelitian pengembangan ini adalah untuk mengetahui tingkat kepraktisan penggunaan $e$-book Fisika berbantuan edmodo berbasis discovery learning dalam prosese pembelajaran. Jenis penelitian ini adalah Research and Development $(R \& D)$. Metode yang digunakan dalam penelitian yaitu metode deskriptif dengan instrumen pengumpulan data yakni angket praktikalitas yang dinilai oleh guru. Penelitian ini dilakukan di Sekolah Menengah Atas Negeri 14 Padang Tahun Ajaran 2019/2020 pada materi gelombang mekanik. Hasil penelitian ini menunjukkan bahwa e-book Fisika berbantuan edmodo berbasis discovery learning sangat praktis digunakan dalam proses pembelajaran dengan persentase rata-rata praktikalitas sebesar $90 \%$.
\end{abstract}

Kata Kunci : Discovery Learning, E-Book, Edmodo, Praktikalitas

\begin{abstract}
The purpose of this research and development was to determine the level of practicality in using e-book of Physics assisted by edmodo based on discovery learning in the learning process. This type of research and Development (R\&D). The method used in this research is descriptive method with data collection instruments, namely practicality questionnaires assessed by the teacher. This research was conducted at State Senior High School 14 Padang for the 2019/2020 academic year on mechanical wave material. The results of this study indicate that the e-book Physics assisted by edmodo based on discovery learning is very pratical to use in the learning process with an average percentage of practicality $90 \%$.
\end{abstract}

Keywords : Discovery Learning, E-Book, Edmodo, Practicality

\section{PENDAHULUAN}

Pendidikan diartikan sebagai sebuah proses dengan menggunakan metode-metode tertentu, sehingga seseorang dapat memperoleh pengetahuan, pemahaman, dan cara bertingkah laku yang sesuai dengan kebutuhan. Pembelajaran merupakan proses paling utama yang dilakukan oleh guru agar terjadinya proses belajar pada diri peserta didik [1]. Fisika merupakan salah satu pembelajaran yang dilakukan di sekolah. Pembelajaran Fisika yang inovatif harus mengikuti perkembangan zaman. Zaman revolusi industri 4.0 memperlihatkan perkembangan teknologi yang sangat pesat, sehingga informasi dapat diakses kapan saja dan dimana saja. Guru ditantang untuk melek terhadap kecanggihan teknologi. Zaman revolusi industri 4.0 ini memungkinkan sistem informasi dan komunikasi untuk menyalin dunia fisik ke dalam bentuk virtual, sehingga guru harus mampu mengembangkan dan menggunakan bahan ajar yang sesuai dengan zaman revolusi industri 4.0 dalam proses pembelajaran [2].

Bahan ajar merupakan bagian penting dari proses pembelajaran. Bahan ajar merupakan segala bentuk bahan yang digunakan untuk membantu guru dalam melaksanakan proses pembelajaran [3]. Bahan ajar juga diartikan sebagai sumber belajar untuk menunjang proses pembelajaran di kelas [4]. Bahan ajar merupakan segala sesuatu yang digunakan untuk mendukung, memfasilitasi, mempengaruhi atau mendorong tercapainya kompetensi peserta didik [5]. Bahan ajar yang sesuai dengan perkembangan zaman salah satunya adalah e-book.

E-book atau electronic book atau dikenal dengan sebutan buku elektronik. E-book merupakan salah satu bahan ajar yang digunakan oleh guru sebagai sumber belajar [6]. E-book merupakan sebuah buku dalam bentuk elektronik yang berisikan materi pembelajaran yang dapat berupa teks maupun gambar [7]. E-book memiliki beberapa kelebihan diantaranya yakni ukuran fisik kecil, mudah dibawa, tidak lapuk, nudah diproses, mudah digandakan, mudah dalam pendistribusian, dan ragam reader [8].

Pembelajaran melalui ICT (Information Communication and Technology) merupakan suatu proses pembelajaran yang memanfaatkan kecanggihan teknologi dalam hal ini menggunakan jaringan internet. Pembelajaran dilangsungkan dengan memasukan e-book ke dalam internet sehingga dapat diakses oleh peserta didik melalui teknologi. Teknologi informasi dan komunikasi merupakan salah sati faktor penting yang memungkinkan kecepatan transformasi ilmu pengetahuan kepada peserta didik, generasi bangsa ini secara luas. Dalam konteks yang lebih spesifik 
dapat dikatakan bahwa kebijakan penyelenggaraan pendidikan, baik yang diselenggarakan pemerintah pemerintah daerah maupun masyarakat luas harus mampu memberikan akses pemahaman dan penguasaan teknologi mutakhir yang luas kepada peserta didik [9].

Penggunaan internet dalam mengakses e-book Fisika membutuhkan sebuah aplikasi. Aplikasi yang digunakan adalam edmodo. Edmodo adalah layanan berbasis internet yang disediakan sebagai sebuah jaringan belajar yang memungkinkan guru berbagi konten pembelajaran, memberi kuis dan tugas [10].

Edmodo adalah sebuah situs pendidikan berbasis social networking yang didalamnya terbata berbagai konten pendidikan [11]. Edmodo memiliki beberapa kelebihan sebagai berikut : 1) closed group collaboration, hanya yang memiliki group code yang dapat mengikuti kelas, 2) free, diakses online dan tersedia untuk perangkat smartphone, android, iphone, 3) tidak memerlukan server di sekolah, 4) dapat diakses dimanapun dan kapanpun, 5) edmodo dapat diaplikasikan dalam satu kelas, satu sekolag, antar sekolah, antar sekolah dalam satu kota atau kabupaten, 6) edmodo digunakan untuk berkomunikasi dengan menggunakan model social media, learning material, dan evaluasim 7) terdapat notifikasi, dan 8) fitur dapat dimanfaatkan untuk meningkatkan motivasi peserta didik [12].

Proses pembelajarn Fisika pada kurikulum 2013 dilaksanakan dengan menggunakan model pembelajaran. Model pembelajaran diartikan sebagai kerangka konseptual yang melukiskan proses sistematis dalam mengorganisasikan pengalaman belajar untuk mencapai tujuan belajar. Salah satu model pembelajaran yang dapat digunakan dalam proses pembelajaran Fisika adalah model discovery learning. Model discovery learning merupakan model pembelajaran yang mendorong peserta didik untuk sampai pada suatu kesimpulan berdasarkan kegiatan dan pengamatan peserta didik sendiri [13].

Discovery learning merupakan suatu model pembelajaran yang melibatkan peserta didik dalam pemecahan masalah untuk pengembangan pengetahuan dan keterampilan [14]. Adapun langkah kerja dari model discovery learning yakni stimulasi, identifikasi masalah, pengumpulan data, pengolahan data, pembuktian, dan menarik kesimpulan [15].

E-book Fisika berbantuan edmodo berbasis discovery learning yang digunakan dalam pembelajaran Fisika merupakan e-book yang praktis. E-book dikatakan praktis jika e-book tersebut dapat dengan mudah digunakan dalam pembelajaran [16]. Praktikalitas juga diartikan sebagai tingkat keterpakaian atau kemudahan e-book untuk digunakan oleh peserta didik dalam proses pembelajaran [17].

Rumusan masalah pada penelitian ini adalah bagaimanakah tingkat kepraktisan e-book Fisika berbantuan edmodo berbasis discovery learning dalam proses pembelajaran Fisika? Berdasarkan rumusan masalah, maka tujuan penelitian ini adalah untuk mengetahui tingkat kepraktisan e-book Fisika berbantuan edmodo berbasis discovery learning dalam proses pembelajaran.

\section{METODE PENELITIAN}

Research and Development/ $R \& D$ (penelitian dan pengembangan) merupakan jenis penelitian yang sesuai dengan permasalahan dan tujuan yang telah dikemukakan. Metode penelitian dan pengembangan dalam bahasa inggris yakni research and development merupakan metode penelitian yang digunakan untuk menghasilkan produk tertentu, dan menguji produk tersebut [18]. Dalam penelitian ini produk yang dihasilkan dan dilakukan pengujian adalah e-book Fisika berbantuan edmodo berbasis discovery learning.

Instrumen yang digunakan untuk mengumpulkan data yakni instrumen praktikalitas oleh guru. Instrumen praktikalitas digunakan untuk mengetahui kepraktisan dari e-book yang dihasilkan. Analisis $e$ book Fisika berbantuan edmodo berbasis discovery learning berupa : 1) kemudahan dalam menggunakan e-book, 2) kemudahan memahami materi dan bahasa yang digunakan dalam e-book, 3) kemudahan dalam menenmukan konsep, 4) meningkatkan aktivitas, kemandirian, menumbuhkan pengalaman belajar, dan motivasi belajar peserta didik, 5) efesiensi pemakaian waktu dan tenaga dalam penggunaan e-book, dan 6) kemenarikan. Nilai praktikalitas dapat ditentukan dengan menggunakan rumus:

$$
\text { Nilai }-\frac{\text { Skor yang Diperoleh }}{\text { Skor Maksimum }} \times 100 \%
$$

Berdasarkan nilai praktikalitas, maka dapat ditentukan kriteria praktikalitas sebagai berikut:

Tabel 1. Kriteria Kepraktisan

\begin{tabular}{ccl}
\hline No & Persentase (\%) & \multicolumn{1}{c}{ Kriteria } \\
\hline 1 & $90-100$ & Sangat Praktis \\
2 & $80-89$ & Praktis \\
3 & $65-79$ & Cukup Praktis \\
4 & $55-64$ & Kurang Praktis \\
5 & $0-54$ & Tidak Praktis \\
\hline
\end{tabular}

Sumber : [19].

\section{HASIL DAN PEMBAHASAN}

Data yang diperolah dalam penelitian ini adalah data praktikalitas e-book Fisika berbantuan edmodo berbasis discovery learning yang dinilai oleh 3 orang guru Fisika SMAN 14 Padang. Penilaian praktikalitas e-book Fisika berbantuan edmodo berbasis discovery learning terdidi atas enam komponen yakni 1) kemudahan dalam menggunakan e-book, 2) kemudahan memahami materi dan bahasa yang digunakan dalam e-book, 3) kemudahan dalam menenmukan konsep, 4) meningkatkan aktivitas, kemandirian, menumbuhkan pengalaman belajar, dan motivasi belajar peserta didik, 5) efesiensi pemakaian watu dan tenaga dalam penggunaan e-book, dan 6) menarik. Hasil analisis uji praktikalitas untuk 
komponen kemudahan dalam menggunakan e-book dapat dilihat pada Gambar 1.

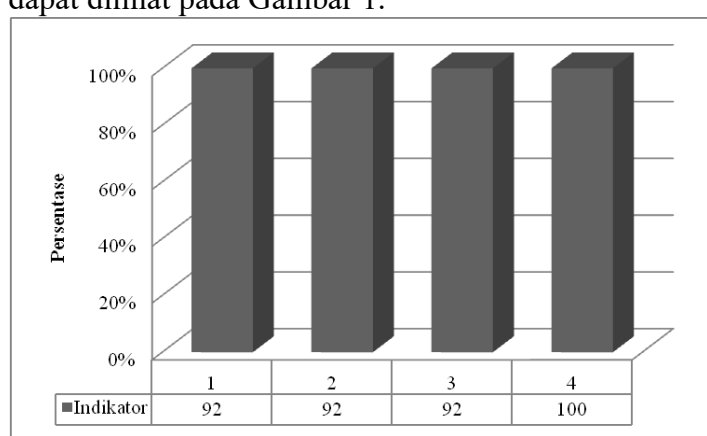

Gambar 1. Komponen Kemudahan dalam Menggunakan E-book

Gambar 1 merupakan hasil analisis uji praktikalitas untuk komponen kemudahan dalam menggunakan e-book. Indikator komponen kemudahan dalam menggunakan e-book terdiri dari Sembilan indikator. Indikator pertama yakni guru mudah menggunakan e-book yang dikembangkan dengan nilai praktikalitas $92 \%$ berada pada kriteria sangat praktis. Indikator kedua yakni guru mengikuti kegiatan pembelajaran yang disajikan di dalam $e$ book dengan baik dengan nilai praktikalitas $92 \%$ berada pada kriteria sangat praktis. Indikator ketiga yakni guru dapat mengevaluasi proses pembelajaran dengan nilai praktikalitas $92 \%$ berada pada kriteria sangat praktis. Indikator keempat yakni guru dapat memiliki akses untuk setiap langkah pembelajaran sesuai dengan model discovery learning dengan nilai praktikalitas $100 \%$ berada pada kriteria sangat praktis.

Persentase rata-rata praktikalitas untuk komponen kemudahan dalam menggunakan e-book adalah $97 \%$ dengan kriteria sangat praktis. Hal ini sesuai dengan kajian teori bahwa e-book dikatakan praktis dari komponen kemudahan dalam penggunaan memiliki persentase $>80 \%$. Hasil analisis uji praktikalitas untuk komponen kemudahan memahami materi dan bahasa yang digunakan dalam e-book dapat dilihat pada Gambar 2.

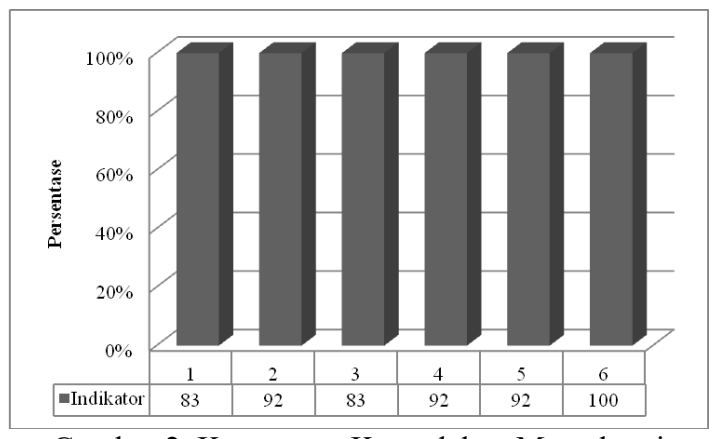

Gambar 2. Komponen Kemudahan Memahami Materi dan Bahasa yang Digunakan dalam e-book

Gambar 2 merupakan hasil analisis uji praktikalitas untuk komponen kemudahan memahami materi dan bahasa yang digunakan dalam e-book yang terdiri dari enam indikator. Indikator pertama yakni materi Fisika terintegrasi materi mitigasi bencana gempa bumi yang disajikan di dalam e-book dapat dipahami oleh guru dengan mudah dengan nilai praktikalitas $83 \%$ berada pada kriteria praktis. Indikator kedua yakni bahasa yang digunakan dalam e-book dapat dipahami oleh guru dengan baik dengan nilai praktikalitas $92 \%$ berada pada kriteria sangat praktis. Indikator ketiga yakni materi Fisika terintegrasi materi mitigasi bencana gempa bumi yang disajikan dalam e-book sistematis dengan nilai praktikalitas $83 \%$ berada pada kriteria praktis.

Indikator keempat yakni bahasa yang digunakan dalam seluruh tahap pembelajaran di dalam e-book komunikatif dengan nilai praktikalitas $92 \%$ berada pada kriteria sangat praktis. Indikator kelima yakni gambar yang disajikan komunikatif dan mudah dipahami dengan nilai praktikalitas $92 \%$ berada pada kriteria sangat praktis. Indikator keenam yakni guru merasa terbantu dalam menyampaikan materi pembelajaran dengan nilai praktikalitas $100 \%$ berada pada kriteria sangat praktis. Persentase rata-rata praktikalitas untuk komponen kemudahan memahami materi dan bahasa yang digunakan dalam e-book adalah 90\% dengan kriteria sangat praktis. Hal ini sesuai dengan kajian teori bahwa e-book dikatakan praktis dari komponen kemudahan memahami materi dan bahasa yang digunakan dalam e-book memiliki persentase $>80 \%$. Hasil analisis uji praktikalitas untuk komponen kemudahan dalam menemukan konsep dapat dilihat pada Gambar 3.

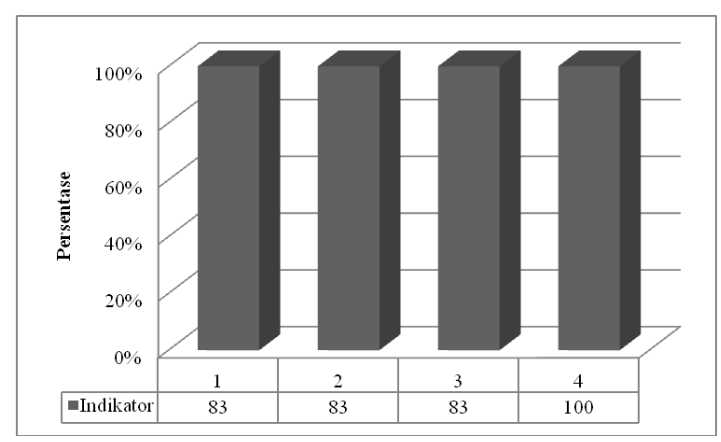

Gambar 3. Komponen Kemudahan Dalam Menemukan Konsep

Gambar 3 merupakan hasil analisis uji praktikalitas untuk komponen kemudahan dalam menemukan konsep yang terdiri dari empat indikator. Indikator pertama yakni peserta didik dapat menemukan konsep Fisika terintegrasi materi mitigasi bencana gempa bumi sendiri melalui materi yang tersedia di dalam setiap tahap pada e-book dengan nilai praktikalitas $83 \%$ berada pada kriteria praktis. Indikator yang kedua yakni peserta didik dapat menemukan konsep Fisika terintegrasi materi mitigasi bencana gempa bumi sendiri karenabahasa yang digunakan komunikatif dengan nilai praktikalitas $83 \%$ berada pada kriteria praktis. Indikator ketiga yakni e-book menyajikan pertanyaan kritis yang dapat memicu peserta didik dalam menemukan konsep Fisika terintegrasi materi 
mitigasi bencana gempa bumi dengan nilai praktikalitas $83 \%$ berada pada kriteria praktis.

Indikator keempat yakni e-book menyajikan langkah pembelajaran yang sistematis sehingga dapat membantu peserta didik dalam menemukan konsep Fisika terintegrasi materi mitigasi bencana gempa bumi dengan nilai praktikalitas $100 \%$ berada pada kriteria sangat praktis. Persentase rata-rata praktikalitas untuk komponen kemudahan dalam menemukan konsep adalah 88\% dengan kriteria praktis. Hal ini sesuai dengan kajian teori bahwa $e$ book dikatakan praktis dari komponen kemudahan dalam menemukan konsep memiliki persentase > $80 \%$. Hasil analisis uji praktikalitas untuk komponen meningkatkan aktivitas, kemandirian, menumbuhkan pengalaman belajar, dan motivasi belajar peserta didik dapat dilihat pada Gambar 4.

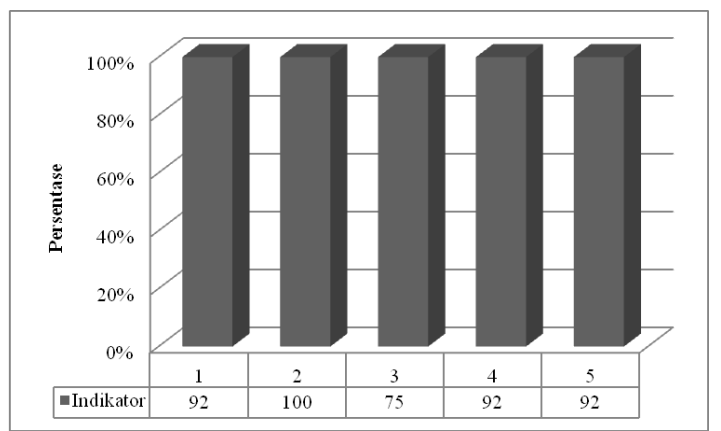

Gambar 4. Komponen Meningkatkan Aktivitas, Kemandirian, Menumbuhkan Pengalaman Belajar, dan Motivasi Belajar Peserta Didik

Gambar 4 merupakan hasil analisis uji praktikalitas untuk komponen meningkatkan aktivitas, kemandirian, menumbuhkan pengalaman belajar, dan motivasi belajar peserta didik yang terdiri dari lima indikator. Indikator pertama yakni peserta didik menjadi lebih aktif dengan menggunakan e-book dalam belajar dengan nilai praktikalitas $92 \%$ berada pada kategori sangat praktis. Indikator kedua yakni e-book membantu peserta didik mandiri dalam belajar dengan nilai praktikalitas $100 \%$ berada pada kriteria sangat praktis. Indikator ketiga yakni e-book membantu peserta didik mengukur kemampuannya dalam menguasai materi Fisika terintegrasi materi mitigasi bencana gempa bumi dengan nilai praktikalitas $75 \%$ berada pada kriteria cukup praktis.

Indikator keempat yakni langkah-langkah dalam pembelajaran e-book memberikan peserta didik pengalaman belajar dengan nilai praktikalitas $92 \%$ berada pada kriteria sangat praktis. Indikator kelima yakni e-book meningkatkan minat belajar peserta didik dengan nilai praktikalitas $92 \%$ berada pada kriteria sangat praktis. Persentase rata-rata praktikalitas untuk komponen meningkatkan aktivitas, kemandirian, menumbuhkan pengalaman belajar, dan motivasi belajar peserta didik adalah $90 \%$ dengan kriteria praktis. Hal ini sesuai dengan kajian teori bahwa e-book dikatakan praktis dari komponen meningkatkan aktivitas, kemandirian, menumbuhkan pengalaman belajar, dan motivasi belajar peserta didik memiliki persentase $>80 \%$. Hasil analisis uji praktikalitas untuk komponen efesiensi pemakaian waktu dan tenaga dalam penggunaan e-book dapat dilihat pada Gambar 5.

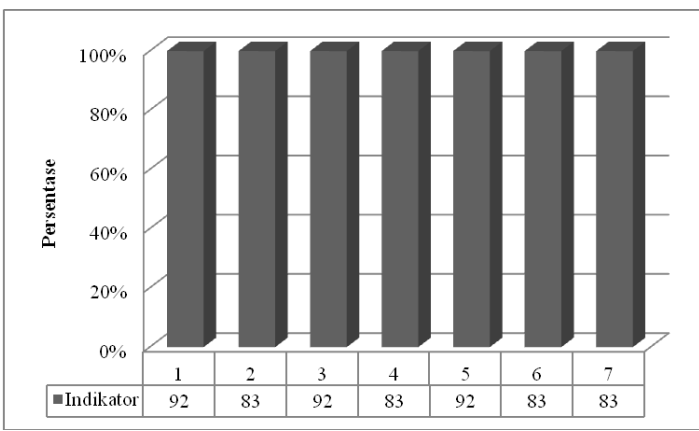

Gambar 5. Komponen Efesiensi Pemakaian Waktu dan Tenaga dalam Penggunaan E-Book

Gambar 5 merupakan hasil analisis uji praktikaltias untuk komponen efesiensi pemakaian waktu dan tenaga dalam penggunaan e-book yang terdiri dari tujuh indikator. Indikator pertama yakni penyajian e-book sederhana sehingga cepat dipahami dengan nilai praktikalitas $92 \%$ berada pada kriteria sangat praktis. Indikator yang kedua yakni kegiatan pembelajaran dalam e-book disampaikan dengan padat dan lugas sehingga cepat dipahami oleh peserta didik dengan nilai praktikalitas $83 \%$ berada pada kriteria praktis. Indikator ketiga yakni semua kegiatan yang disajikan pada e-book dapat diikuti dan dijalani dengan nilai praktikalitas $92 \%$ berada pada kriteria sangat praktis. Indikator keempat yakni e-book dapat saya gunakan dalam waktu relatif singkat dengan nilai praktikalitas $83 \%$ berada pada kriteria praktis.

Indikator kelima yakni e-book membantu guru menyelesaikan pembelajaran tepat waktu dengan nilai praktikalitas $93 \%$ berada pada kriteria sangat praktis. Indikator keenam yakni e-book dapat menghemat penggunaan waktu guru dalam mengajar dengan nilai praktikalitas $83 \%$ berada pada kriteria praktis. Indikator ketujuh yakni pembelajaran melalui e-book dapat tepat waktu dengan nilai praktikalitas $83 \%$ berada pada kriteria praktis. Persentase rata-rata praktikalitas untuk komponen komponen efesiensi pemakaian waktu dan tenaga dalam penggunaan e-book adalah $87 \%$ dengan kriteria praktis. Hal ini sesuai dengan kajian teori bahwa e-book dikatakan praktis dari komponen efesiensi pemakaian waktu dan tenaga dalam penggunaan e-book memiliki persentase $>80 \%$. Hasil analisis uji praktikalitas untuk komponen kemenarikan dapat dilihat pada Gambar 6. 


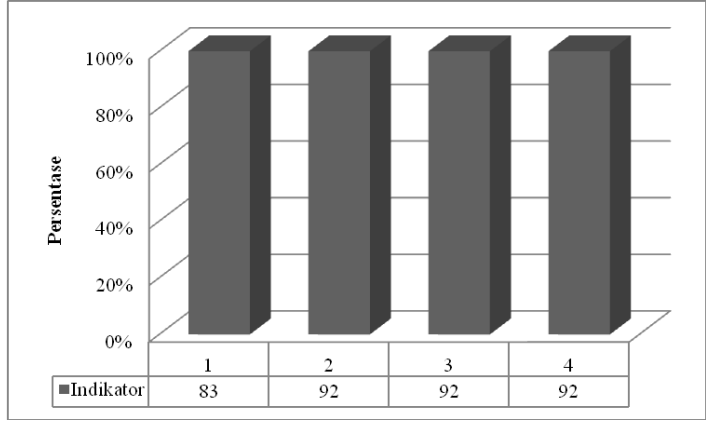

Gambar 6. Kemenarikan

Gambar 6 merupakan hasil analisis uji praktikalitas untuk komponen kemenarikan yang terdiri atas empat indikator. Indikator pertama yakni penyajian materi Fisika terintegrasi materi mitigasi bencana gempa bumi dalam e-book memunculkan ketertarikan untuk diketahui lebih lanjut dengan nilai praktikalitas $83 \%$ berada pada kriteria praktis. Indikator kedua yakni langkah kegiatan pembelajaran dalam e-book disajikan dengan menarik dengan nilai praktikalitas $92 \%$ berada pada kriteria sangat praktis.

Indikator ketiga yakni peserta didik senang menggunakan e-book dalam pembelajaran dengan nilai praktikalitas $92 \%$ berada pada kategori sangat praktis. Indikator keempat yakni peserta didik bersemangat dalam belajar dengan menggunakan $e$ book dengan nilai praktikalitas $92 \%$ berada pada kriteria sangat praktis. Persentase rata-rata praktikalitas untuk komponen komponen kemenarikan adalah 90\% dengan kriteria sangat praktis. Hal ini sesuai dengan kajian teori bahwa $e$ book dikatakan praktis dari komponen kemenarikan memiliki persentase $>80 \%$. E-book Fisika berbantuan edmodo berbasi discovery learning memiliki persentase rata-rata untuk kelima komponen yakni $90 \%$ berada pada kriteria sangat praktis., sehingga e-book Fisika sangat praktis digunakan dalam proses pembelajaran Fisika.

\section{KESIMPULAN}

Berdasarkan hasil dan pembahasan dalam penelitian ini dapat disimpulkan bahwa e-book Fisika berbantuan edmodo berbasis discovery learning praktis digunakan dalam proses pembelajaran Fisika.

\section{DAFTAR PUSTAKA}

[1] Ernawati., \& Efendi. (2017). Penerapan Lesson Study pada Pembelajaran Fisika Materi Perubahan Wujud Zat. Jurnal Inovasi Pendidikan Fisika dan Riset Ilmiah, 1(2). 41.

[2] Ayu, F., \& Ahmad, F. (2020). Analysis of Student Response to Eartquakw Disaster in High School Physics Learning. The 2019 Int. Conf. on Research and Learninf of Physics. $1481012044: 3$

[3] Asrizal., Khairani, S., \& Harman, H. (2017). Pengembangan Bahan Ajar IPA Terpadu
Berorientasi Pembelajaran Kontekstual Tema Pemanfatan Tekanan dalam Kehidupan untuk Meningkatkan Literasi Siswa Kelas VIII SMP. Pillar of Physics Education, 10(1). 154.

[4] Azrizal., Ali, A., Azwar, A., \& Festiyed. (2019). Effects of Science Student Worksheet of Motion in Daily Life theme in Adaptive Contextual Teaching Model on Academic Achievement of Students. The 2018 Int. Conf. on Research and Learning of Physics. 1185 $012093: 2$.

[5] Asrizal., Ali, A., Ananda, A., Festiyed., \& Suci, K. (2018). Effectiveness of Integrated Science Instructional Material on Pressure in Daily Life theme to Improve Digital Age Literacy of Students. International Conference on Science Education. 1006 012031 : 3 .

[6] Wilujeng, I., \& Sri, M. (2013). Pengembangan Media E-Book Interaktif Melalui Strategi Mind Mapping pada Materi Pokok Listrik Dinamis untuk SMA Kelas X. Jurnal Inovasi Pendidikan Fisika, 2(2). 55-56.

[7] Hidayat, A., Agus, S., \& Wayan, S. (2017). Pengembangan Buku Elektronik Interaktif pada Materi Fisika Kuantum Kelas XII SMA. Jurnal Pendidikan Fisika, 2(2) : 39.

[8] Fani, I. T. (2016). Pengembangan E-Book Interaktif Elektrokimia Berabasi Kehidupan Sehari-Hari. Bandar Lampung : Universitas Lampung.

[9] Darmawan, D. (2011). Teknologi Pembelajaran. Bandung : Remaja Rosda Karya.

[10] Hakim, A. B. (2016). Efektifitas Penggunaan E-Learning Moodle, Google Classroom, dan Edmodo. I-Statement, 2(1) : 2.

[11] Daulay, U. A., Syarifuddin., \& Binari, M. (2016). Pengaruh Blended Learning Berbasi Edmodo dan Motivasi Belajar Terhadap Hasil Belajar IPA Biologi dan Retensi Siswa pada Sistem Peredaran Darah Manusia di Kelas VIII SMP Negeri 5 Medan. Jurnal Pendidikan Biologi, 6(1) : 261.

[12] Dwiharja, L. M. (2015). Memanfaatkan Edmodo sebagai Media Pembelajaran Akuntasi. Prosiding Seminat Nasional. 335.

[13] Atika, D., Murbangun, N., \& Sri, N. (2018). Pengaruh Metode Discovery Learning Berbantuan Video Terhadap Hasil Belajar Siswa SMA. Jurnal Inovasi Pendidikan Kimia, 12(2). 2150.

[14] Yuliana, N. (2018). Penggunaan Model Pembelajaran Discovery Learning dalam 
Jurnal Inovasi Pendidikan dan Sains

Vol. 1 No. 3, Desember 2020 : 66-71

ISSN 2721-9119 (Online)

Peningkatan Hasil Belajar Siswa di Sekolag Dasar. Jurnal Ilmiah Pendidikan dan Pembelajaran PPS Universitas Pendidikan Ganesha, 2(1): 32 .

[15] Rosdiana,. Didimus, T. B., \& Susilo. (2017). Pengaruh Penggunaan Model Discovery Learning terhadap Efektivitas dan Hasil Belajar Siswa. Jurnal Pendidikan, 2(8). 10611062.

[16] Andromeda., Ellizar., Iryani., Bayharti., \& Yulmasari. (2018). Validitas dan Praktikalitas Modul Laju Reaksi Terintegrasi Eksperimen dan Keterampilan Proses Sains untuk Pembelajaran Kimia di SMA. Jurnal Eksakta Pendidikan, 2(2). 137.

[17] Agustyaningrum, N., \& Yesi, G. (2017). Praktikalitas dan Keefektifan Modul Geometri Analitik Ruang Berbasis Konstruktivismer. Jurnal Dimensi, 6(3). 414.

[18] Sugiyono. (2012). Metode Penelitian Kuantitatif. Kualitatif, dan $R \& D$. Bandung : Alfabeta.

[19] Syahmaidi, E., \& Hendra, H. (2016). Praktikalitas Perancangan Media e-Learning Berbasis Video. Jurnal Nasional Pendidikan Teknik Informatika, 5(2). 91. 